\title{
Performing Arts Experiment of Central Java Amidst the Covid-19 Pandemic
}

\author{
Khothibul Umam ${ }^{1 *}$, Suharyo ${ }^{1}$, Fajrul Falah ${ }^{1}$, and Gregorius Tri Hendrawan Manurung ${ }^{1}$ \\ ${ }^{1}$ Department of Indonesian Literature, Faculty of Humanities, Diponegoro University, Semarang - \\ Indonesia
}

\begin{abstract}
The research aimed to investigate three cultural events: Panggung Kahanan, Lembah Gana Festival, and Semarang musicians' movement, along with their cultural strategy amidst the Covid-19 pandemic. The method used in the research was the Sociology of Art approach, focusing on the event and artwork productions. The data were collected from the interviews with the artists involved in Panggung Kahanan and Lembah Gana Festival events and Semarang musicians. The data collection methods used in the research were observation and in-depth interviews. The observation method covered the data related to the event and work productions. The in-depth interview covered the data related to the event and work concepts. The analytical method used in the research was to investigate how far the art experiment had an impact on the performing arts ecosystem in Central Java and the cultural strategy for the art and cultural resilience amidst the Covid-19 pandemic. The research showed that the Covid-19 pandemic opened many new opportunities to continue experimenting and adapting in the art and cultural areas in Central Java.
\end{abstract}

\section{Introduction}

In early In early 2020, the Covid-19 case turned into a global pandemic, including in Indonesia. The social distancing enforcement as a means to prevent the spread of Covid-19 immediately changed the social life. Performing arts that needed live interaction between the artists and audience became a group with the most significant impact. Various genres of performing arts faced the same problem. From theatre, music to dance. From traditional to modern arts.

Various kinds of art and entertainment productions were cancelled or postponed. Until early April 2020, there were ten postponed film production and release processes, so did 40 concerts, tours, and music festivals; eight exhibitions at fine arts museums; three dance performances; and nine theatre performances, pantomime, and puppet [1]. The number kept rising that there were 234 art events cancelled or postponed, 37.000 artists or art workers lost their income amidst the pandemic, and 189.586 art and creative workers, from musicians, stage crews, and film crews were fired and sent home [2].

As one of the art epicenters in Indonesia, Central Java faced a problem when the performing arts workers could no longer hold a performance. With no performance, the artists

* Corresponding author: khothibulumam@,1ecturer.undip.ac.id 
automatically lost their income. People conducted various kinds of experiments and adaptations to overcome the problem. Panggung Kahanan was one of the events they held. It was a virtual show in the official residence of the Governor of Central Java, Ganjar Pranowo, in 2020 [3]. The next edition took place in TVRI Central Java, followed by the performances around six towns in Central Java in 2021. It also became an event to raise a donation for the artists of Central Java.

Lembah Gana Festival 2020 was another adaptation in Semarang Regency. Because of the Covid-19 pandemic, the event took place in Lembah Gana, specifically at Ganesha and Watu Kelir sites, and aired on YouTube virtually. Applying a strict health protocol around the Ganesha site, they recorded the performance, and it aired virtually in cyberspace afterwards [4].

Furthermore, several music groups in Semarang eventually turned their stages into virtual. Various indie bands, including Wiwiek ' $n$ Friends, Soegi Bornean, Santikarisma, and Tridhatu, released their singles on different media, like YouTube and Spotify. They also planned a virtual show on YouTube and Instagram.

Research on various kinds of art activities amidst the pandemic is essential. People must preserve art as one of the evidences of human's resilience in survival. The research aimed to record every adaptation and experience process of the artists and cultural practitioners to continue living their lives in any condition.

\section{Literature Review}

For a long time, performing arts have had a significant position among the people of Indonesia. People use various performing arts in religious rites, traditional ceremonies, expressions of social and political criticism and infiltrate everyday life. It can also function as an appointing power, strengthening the social relationship and celebrating collective values [5].

Performing arts have a unique atmosphere, an "occurrence" where interaction occurs between performers (read: artists) and the audience. There is a live interaction between them; they see and feel each other in the same atmosphere. Nothing can replace it in the virtual stage [6].

Given the overview, it is utterly understandable that performing arts are one of the art genres that is most affected by the Covid-19 pandemic. The absence of stages and performances because of the social distancing hits the vitality of the performance artists. Dadang Dwi Septiyan conducted one of the research regarding performing arts. Dadang's research concluded that the Covid-19 pandemic harmed the continuity of music culture. Changing media into the virtual performance gave rise to a distance between the performers and audience, reducing the interaction among people that led to dehumanization [7]. Puji Hastuti researched how Jakarta indie musicians applied the adaptation in facing the Covid19 pandemic. Hastuti wrote and analyzed the phases and practice of adaptation in the Jakarta indie music ecosystem in the first wave of the Covid-19 pandemic by applying the anthropological approach. The practices of adaptation of Jakarta indie music ecosystem were 1) communal solidarity, 2) creative habitual adaptability, 3) exploration of digital communal space, and 4) contemplation period presenting the new work [8].

This research will focus on how a pandemic eventually made performance artists in Central Java experiment and adapt for survival and cultural resilience. 


\section{Research Method}

The research was included in the category of field research. The basis of the research was sociology, which worked based on qualitative research. The approach used in the research was Sociology of Art, which notably discussed or examined people with specific involvement in art activities and other people outside art activities who were involved in the cultural phenomenon that influenced the art activities. The principal study was the people as connoisseurs, observers, reviewers, researchers, educators (consumers), and organizers of arts as the components of the art creation process $[9,10,11]$. The research data resulted from the interviews with the artists involved in Panggung Kahanan event and the committee/team of Panggung Kahanan. We interviewed 3 (three) core committees, Vikkir Rahman, Prabowo, and Aristya Kusuma Verdana. From them, we obtained the data concerning Panggung Kahanan in 3 (editions). Besides, we also interviewed other artists directly, including Lik Mogol, a ketoprak art worker from Pati and Joko Jazz, a scenographer from Solo. For Lembah Gana Festival, we interviewed Tri Subekso, one of the members of the initiator team of the event and Pamong Budaya (Culture Guardian) of Semarang Regency. The artists we interviewed included the team of Wayang Tenda, Sanggar Tari Nyi Pandansari, and a music group Tridhatu. For the movement of Semarang musicians, we interviewed Erick Parkers, a manager of various bands in Semarang; Radika, the vocalist of Wiwiek 'N Friends; and Aristya Kusuma Verdana from a music group Tridhatu. The data collection methods were observation and in-depth interviews. The observation method covered the data regarding the event and work productions. The in-depth interview method covered the data regarding cultural strategy applied amidst the Covid-19 pandemic. The analytical method investigated how far the artists, with their experiment, innovation, and adaptation, impacted the performing arts ecosystem in Central Java and what kind of cultural strategy applied for the resilience of art and culture amidst the Covid-19 pandemic.

\section{Experiment, Innovation, and Adaptation of Central Java Performing Arts Amidst the Covid-19 Pandemic}

\subsection{Panggung Kahanan: Virtual Performance and Art Donation}

Panggung Kahanan was a virtual show held by the Governor of Central Java, Ganjar Pranowo, during Ramadan 2020. It also became an event to raise a donation for the artists of Central Java [3]. In the second edition, Panggung Kahanan took place in TVRI Central Java in 10 episodes. Subsequently, the last edition of Panggung Kahanan was held in Ramadan 2021, traveling to 6 (six) towns, including Kendal, Pati, Magealng, Banyumas, Surakarya, and Pekalongan. Ganjar Pranowo posted the entire show on his YouTube channel and Facebook account.

The social distancing enforcement led their choice to fall into a virtual show concept. The adaptation to virtual form could not indeed meet all the art performers' satisfaction. There were several missing elements, from the live audience's reactions to the stuttering of the actors, especially the traditional artists, in the virtual show concept.

However, as a cultural event amidst the Covid-19 pandemic, Panggung Kahanan was a successful event. The event provided opportunities to the artists and cultural actors and the Micro, Small, and Medium Enterprises to continue working and receiving economic returns. There were hundreds of artists and cultural actors who received cash transfers, working grants, and art and cultural events productions. Panggung Kahanan can be a model to create art and cultural events amidst the social distancing and strict health protocol. Preserving this kind of cultural strategy is essential amidst the pandemic. 


\subsection{The Adaptation and Collaboration of Semarang Musicians in the Digital Space}

Semarang Semarang musicians performed the most dominant practice to overcome the social distancing enforcement by doing a virtual concert. They held virtual concerts either independently or collaboratively with other parties, such as music collectives and companies commercially. Bunyi dari Rumah concert, a collaboration between Kolektif Hysteria, SA Corp, and Semarang on Fire, was an example. Bunyi dari Rumah ran weekly throughout May-April 2020, with six concerts in total, presenting two Semarang musicians across generations in every concert.

The music group Tridhatu also conducted a digital space optimization as a strategy to overcome the distance. On December 5th, 2020, Tridhatu performed at a virtual concert by Rahasia Mafiusa, a non-profit organization from South Africa. From Darkness to Light: STAND UP-WISE UP! united 15 Indonesian and South African artists. Aristya Kusuma Verdana, a member of Tridhatu, stated that the pandemic opened up a broader space through internet optimization. Besides presenting their work to the public outside Indonesia, for Verdana, internet and digital space optimization during the pandemic could unite the creative poles in various countries.

Soegi Bornean and Pyong-Pyong took another step. According to Erick Parkers, the manager of Soegi Bornean and Pyong-Pyong, the band crews who depended their lives on concerts were the ones who had the most significant impact amidst the Covid-19 pandemic. Several offers to perform on virtual concerts helped the bands' finances, for they still get paid. To overcome the financial problem of the bands, together with several bands that he managed, Erick collaborated with people from creative industries outside the music sector, such as culinary and clothing lines.

On the other side, people also made an effort to organize a live concert by applying a strict health protocol. Wiwiek 'n Friends was one of the bands who managed to do it. They limited the audience to 50 people, temperature check before entering the venue, and the physical distancing. Radika, the vocalist of Wiwiek' n Friends, stated that the live concert could happen by dint of the collaboration among parties, both during the preparation and execution. The network of friends in the music sector and theatre helped them prepare the concert.

\subsection{The Cultural Resilience à la Lembah Gana Festival}

Lembah Gana Festival was a cultural festival at an archaeological site in the Semarang Regency area. Komunitas Budaya Karangjati Nyawiji [Karangjati Nyawiji Cultural Community] initiated and executed this cultural festival. They designed it to gather the artists, cultural activists, cultural practitioners, archaeologists, historians, and the general public. The theme of the festival was "Knowing the Earth, Nurturing the Memory". The Ganesha statue became the festival's inspiration to introduce the ancestors' culture to the current generation.

People can see the whole Lembah Gana Festival virtually. They recorded the performances and posted them on Lembah Gana Festival's YouTube channel, starting from the ritual and ceremony, sendratari [the art, theatre, and dance], shadow puppet, contemporary puppet, art installation using natural ingredients, musical performance, and so on.

Besides various performances, they also held Javanese Cultural workshops, including writing Javanese scripts and writing on the lontar leaves. The workshops marked the distinction among other festivals. Aside from the festive performances, culture-based educational materials were also present, targeting the youth. 
The festival got its funding from the Facilitation of the Cultural Sector of the Ministry of Education and Culture in the Public Space Utilization category. Judging from the event concept and result, they made good use of the fund. As a premier event, the festival united the local communities and gave valuable education regarding Ancient Javanese culture-based cultural resilience.

\section{Conclusion}

The harsh condition amidst the Covid-19 pandemic indirectly opened up many opportunities in expanding the art and cultural ecosystem. The cultural actors in Central Java started to experiment, innovate, adapt, and collaborate across sectors that used to be unimaginable. The optimization of technology and digital space gave them new practices that can support the continuity of the cultural ecosystem. The potentials are beneficial to developing Central Java's cultural ecosystem if it continues and develops, even when the Covid-19 subsides or ends in Indonesia.

\section{References}

1. L. Safriana, (2020), Tantangan Berat Seniman Pertunjukan di Masa Pandemi Corona. Retrieved from https://katadata.co.id/muchamadnafi/indepth/5e9a41c87f85e/tantanganberat-seniman-pertunjukan-di-masa-pandemi-corona

2. H. Gumay, (2020), Menyoal Kebijakan Kartu Prakerja untuk Seniman Terdampak Pandemi, Retrieved from https://koalisiseni.or.id/menyoal-kebijakan-kartu-prakerjauntuk-seniman-terdampak-pandemi/

3. W. Fajriah, (2020), Panggung Kahanan, Ajang Donasi untuk Seniman Terdampak Covid19. Retrieved from https://news.okezone.com/read/2020/05/12/512/2212647/panggungkahanan-ajang-donasi-untuk-seniman-terdampak-covid-19

4. R. Agung, (2020), Menulis di Daun Lontar, Generasi Muda Mengingat dan Mengenal Sejarah Kebudayaan, Retrieved from https:/www.suaramerdeka.com/regional/semarang/ 246551-menulis-di-daun-lontargenerasi-muda-mengingat-dan-mengenal-sejarah-kebudayaan?page $=1$

5. Ba. Hatley, Pertunjukan Budaya Indonesia Pasca Orde Baru, in Seni Pertunjukan Indonesia Pasca Orde Baru, 3, (2014)

6. S. Dewi, Seni dalam Lipatan Pandemi" (Pidato Seni Dies Natalis Institut Kesenian Jakarta ke-50), 6, (2020)

7. D. D. Septiyan, Perubahan Budaya Musik di Tengah Pandemi Covid-19, in Jurnal Musikolastika: Jurnal Pertunjukan Dan Pendidikan Musik, 2(1), 31-38 (2020)

8. P. Hastuti. Dinamika Industri Musik Indie Jakarta dan Wilayah Sekitarnya Pada Masa Pandemi Covid-19 Gelombang Pertama, in Jurnal Masyarakat Indonesia, 46(2), 221-239 (2020)

9. R. Escarpit, Sosiologi Sastra, 1-2 (2005)

10. S. D. Damono, Sosiologi Sastra: Sebuah Pengantar Ringkas, 3-5 (1978)

11. J. Wolff, The Social Production of Art (Second Edition), 40-48 (1993) 